\title{
Prediksi Jumlah Penjualan Air Mineral Pada Perusahaan "XYZ” Dengan Jaringan Saraf Tiruan
}

\author{
Kusuma Dewangga, S.Kom. \\ Jurusan Ilmu Komputer \\ Universitas Gadjah Mada \\ Jl. Bulaksumur, Yogyakarta \\ kusumadewangga@gmail.com
}

\begin{abstract}
ABSTRAK
Propagasi balik adalah sebuah metode pengenalan suatu pola melalui supervisi, dimana diperlukan pembelajaran terlebih dahulu setelah itu tahap uji data. Studi kasus pada penelitian ini terkosentrasi pada data penjualan air mineral kemesan pada perusahaan yang bertempat di Surabaya. Permasalahan pada perusahaan air mineral ini adalah sulitnya mengalokasikan sumber daya untuk melakukan produksi pada saat permintaan pasar melonjak. Dari permasalahan tersebut, diperlukan suatu prediksi sebagai alat penunjang pengambilan keputusan untuk mengetahui perkiraan permintaan pasar. Pemanfaatan algoritma propagasi balik akan digunakan pada data penjualan air mineral sehingga dihasilkan suatu prediksi atau perkiraan. Berdasarkan prediksi ini perusahaan ingin mengalokasikan sumber daya yang diperlukan untuk memenuhi kebutuhan pasar. Adapun berbagai permasalahan yang dihadapi dalam implementasi algoritma propagasi balik untuk prediksi, yaitu: bagaimana memodelkan Jaringan Saraf Tiruan yang dipakai untuk metode propagasi balik ini, bagaimana data yang digunakan untuk input kedalam Jaringan Saraf Tiruan agar dapat diproses dengan baik, dan bagaimana akurasi prediksi yang dihasilkan dari Jaringan Saraf Tiruan yang sudah diimplementasikan. Kemampuan metode propagasi balik untuk melakukan prediksi cukup efektif namun ada baiknya jika data dari pola ditambahkan.
\end{abstract}

Kata Kunci: Jaringan Saraf Tiruan, Propagasi Balik, Air Mineral, Prediksi, Data Penjualan 


\section{PENDAHULUAN}

Jaringan Saraf Tiruan(JST) merupakan cabang ilmu yang berusaha memetakan pola pikir manusia kedalam komputer. Jaringan Saraf Tiruan dibentuk dari generalisasi model matematis. Model dari jaringan saraf tiruan ini ada berbagai macam, khusus pada kasus ini digunakan model Backpropagation. Objek studi kasus pemanfaatan Jaringan Saraf Tiruan ini digunakan padadata transaksi penjualan Perusahaan Air Minum tertentu yang bertempat di Surabaya. Dengan memanfaatkan Jaringan Saraf Tiruan ini diharapkan pengelola perusahaan mengetahui berapa jumlah sumber daya pada perusahaan yang diperlukan untuk memenuhi permintaan pasar dalam kurun waktu tertentu terhadap produk air minum.

\section{METODOLOGI PENELITIAN}

\section{A. Jaringan Saraf Tiruan(JST)}

Jaringan Saraf Tiruan adalah sistem pemrosesan informasi atau data yang cara kerjanya mirip dengan jaringan saraf biologi. Jaringan saraf tiruan dibentuk sebagai generalisasi model matematika dari jaringan saraf biologi dengan asumsi bahwa:

1. Pemrosesan informasi terjadi pada elemen sederhana yang disebut dengan neuron.

2. Sinyal dikirimkan diantara neuron-neuron melalui penghubung-penghubung.

3. Penghubung antar neuron memiliki bobot yang akan dmemerkuat atau memperlemah sinyal.

Untuk menentukan output, setiap neuron menggunakan fungsi aktivasi yang dikenakan pada jumlah inputan yang diterima. Besarnya output ini selanjutnya dibandingkan dengan sinyal output. Karakteristik jaringan saraf tiruan ditentukan oleh tiga hal:

1. Pola penghubung antar neuron disebut dengan arsitektur jaringan.

2. Metode untuk menentukan bobot penghubung disebut dengan metode pelatihan(training) danpembelajaran(learning).

3. Fungsi aktivasi.

Jaringan saraf tiruan terdiri dari banyak elemen sederhana yang disebut dengan neuron, unit, sel, atau node(vertex). Masing-masing neuron ini nantinya terhubung dengan neuron yang lain yang disebut sebagai edge. Edge ini memiliki nilai bobot 
sendiri-sendiri. Bobot tersebut mewakili informasi yang digunakan oleh jariingan saraf tiruan untuk menyelesaikan masalah. Tiap neuron memiliki kondisi awal yang disebut dengan aktivasi yaitu fungsi yang digunakan untuk menerima sinyal inputan. Biasanya neuron mengirimkan aktivasinya sebagai sinyal ke beberapa neuron yang lain. Penting untuk diketahui bahwa neuron hanya bisa mengirimkan satu kali sinyal pada saat yang sama meskipun sinyal tersebut dikirimkan secara broadcast ke beberapa neuron yang lain.

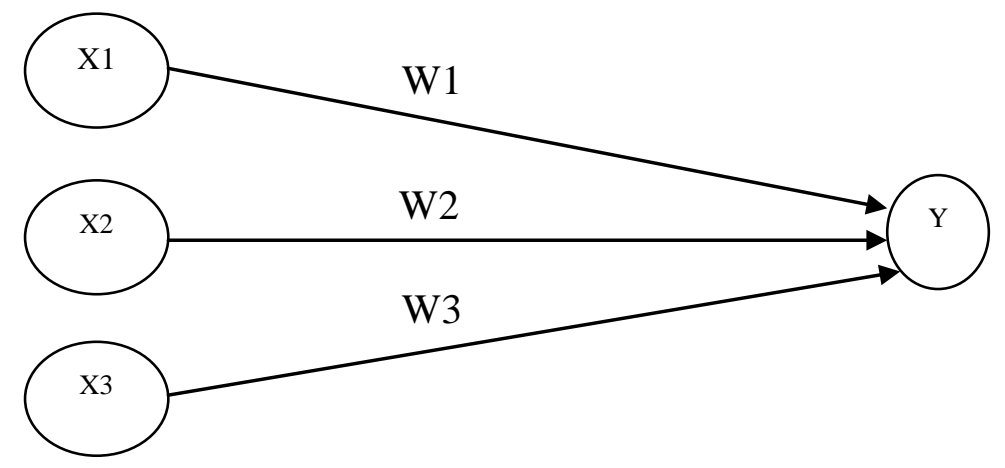

\section{Gambar Contoh Jaringan Saraf Tiruan}

Neuron Y akan menerima inputdari neuron X1,X2, dan X3. Sinyal output neuron tersebut adalah $\mathrm{X} 1, \mathrm{X} 2$, dan X3. Bobot yang dari X1,X2, dan X3 ke neuron $\mathrm{Y}$ adalah W1,W2, dan W3. Inputan y_in ke neuron Y dapat dinotasikan sebagai berikut.

$$
y_{\text {in }}=w_{1} x_{1}+w_{2} x_{2}+w_{3} x_{3}
$$

\section{B. Jaringan Saraf Biologi}

Otak manusia memiliki struktur yang sangat kompleks, karena terdiri dari neuron-neuron dan penghubung yang disebut sinapsis. Neuron bekerja berdasarkan sinyal yang diberikan pada neuron sebelumnya. Kemudian neuron tersebut meneruskannya pada neuron yang lain. Neuron biologi terdiri dari tiga komponen yaitu: dendrit, soma, dan axon. Dendrit menerima sinyal dari neuron-neuron yang lain. Sinyal tersebut adalah sinyal listrik yang dikirimkan melalui sinapsis dengan cara proses kimiawi. Melalui proses kimiawi tersebut, sinyal yang diterima diubah terus menerus hingga melakukan adaptasi sesuai dengan lingkungan yang diperlukan. Proses inilah yang mirip dengan proses perubahan bobot pada jaringan saraf tiruan.Dalam Jaringan saraf tiruan soma diperlakukan sebagai vertex dan axon atau penghubung antar soma diperlakukan sebagai edge.Berikut ini adalah gambar jaringan saraf biologis pada manusia. 


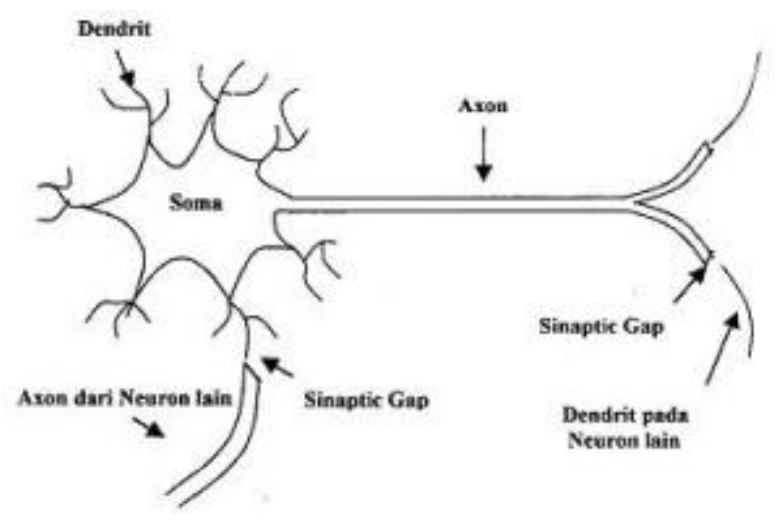

Gambar Jaringan Saraf Biologis

\section{Model Jaringan Saraf Backpropagation}

Jaringan saraf Backpropagation memiliki beberapa unit yang ada dalam satu atau lebih layar tersembunyi(hidden layer). Gambar 3 menunjukan model jaringan backpropagation dengan 3 buah masukan dengan 1 bias, 3 buah hidden layer dengan 1 bias, dan 3 buah ouput layer.

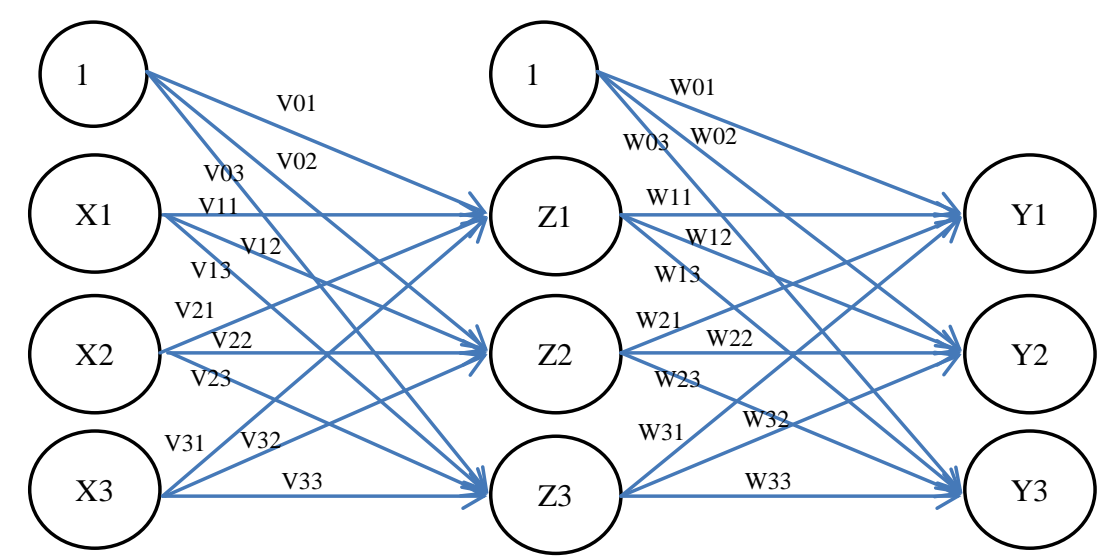

Gambar Model Backpropagation

Notasi $\mathrm{V}_{\mathrm{ij}}$ merupakan garis bobot dari unit masukan $\mathrm{x}_{\mathrm{i}}$ ke unit layar tersembunyi $\mathrm{z}_{\mathrm{j}}\left(\mathrm{V}_{0 \mathrm{j}}\right.$ merupakan garis bobot yang menghubungkan bias di unit masukan ke unit layar tersembunyi $\mathrm{z}_{\mathrm{j}}$ ). Notasi $\mathrm{W}_{\mathrm{kj}}$ merupakan garis bobot dari unit layar tersembunyi $\mathrm{z}_{\mathrm{j}}$ ke unit keluartan $\mathrm{Y}_{\mathrm{k}}\left(\mathrm{w}_{\mathrm{k} 0}\right.$ merupakan garis bobot dari bias di layar tersembunyi ke unit keluaran $\mathrm{Z}_{\mathrm{k}}$ ).

\section{Fase Training Backpropagation}

Fase training backpropagation terdiri dari 3 fase yaitu fase feedforward, fase backpropagation error, dan fase pembaharuan nilai bobot.Ketiga fase ini adalah fase utama yang terus menerus dilakukan hingga mencapai suatu kondisi berhenti dari batas toleransi yang sudah diberikan. 
Fase feedforward adalah fase umpan balik data masukan $\mathrm{X}_{\mathrm{i}}$ disebarkan kedalam hidden layer menggunakan fungsi aktivasi yang telah ditentukan. Hasil perhitungan dari setiap hidden layer $\left(\mathrm{Z}_{\mathrm{j}}\right)$ selanjutnya disebarkan lagi ke layer tersembunyi diatasnya(apabila ada) dan seterusnya sehingga didapatkan hasil output jaringan $\left(\mathrm{Y}_{\mathrm{k}}\right)$. Selanjutnya output jaringan $\left(\mathrm{Y}_{\mathrm{k}}\right)$ dibandingkan dengan target yang harus dicapai $\left(\mathrm{t}_{\mathrm{k}}\right)$. Selisih antara $\left(t_{k}-y_{k}\right)$ adalah error yang terjadi. Jika kesalahan atau error ini lebih kecil dari batas tolertansi yang ditentukan maka proses looping dihentikan. Jika Sebaliknya, maka proses perhitungan akan dilanjutkan dengan memodifikasi bobot tiaptiap garis dalam jaringan untuk mengurangi kesalahan yang terjadi.

Sinyal keluaran dari setiap unit pada lapisan keluaran akan dibandingkan dengan targetnya masing-masing yang telah didefinisikan untuk pola masukan tersebut sehingga akan dihasilkan error (kesalahan) untuk setiap unitnya. Apabila error masih lebih besar daripada threshold yang ada maka dilakukan umpan balik dari output kedalam hiddenlayer hingga input layer.

Setelah sampai kedalam hidden layer dari propagasi balik maka dilakukan perhitungan nilai bobot yang baru. Bobot ini nantinya mengganti bobot yang lama yaitu $\mathrm{V}_{\mathrm{ij}}$ dan $\mathrm{W}_{\mathrm{kj}}$. Demikian seterusnya hingga memenuhi kondisi threshold yang telah diinginkan.

\section{E. Fungsi Aktivasi}

Data penjualan air mineral dalam bulan atau tahun sebelumnya harus ditrasformasikan terlebih dahulu sebelum digunakan pada saat pelatihan atau training. Untuk mentransformasikan data penjualan air mineral tersebut digunakan fungsi aktivasi sigmoid. Fungsi aktivasi yang dipakai harus memenuhi beberapa syarat yaitu: continue, differensiable, dan merupakan fungsi yang tidak turun. Salah satu fungsi sigmoid biner dan fungsi sigmoid bipolar. Fungsi sigmoid biner memiliki range $(0,1)$ dengan rumus sebagai berikut.

$$
f(x)=\frac{1}{1+e^{-x}}
$$

Apabila persamaan tersebut diturunkan maka persamaan tersebut menjadi.

$$
f^{\prime}(x)=f(x)(1-f(x))
$$

Apabila digambarkan Grafik fungsi sigmoid biner tersebut menjadi. 


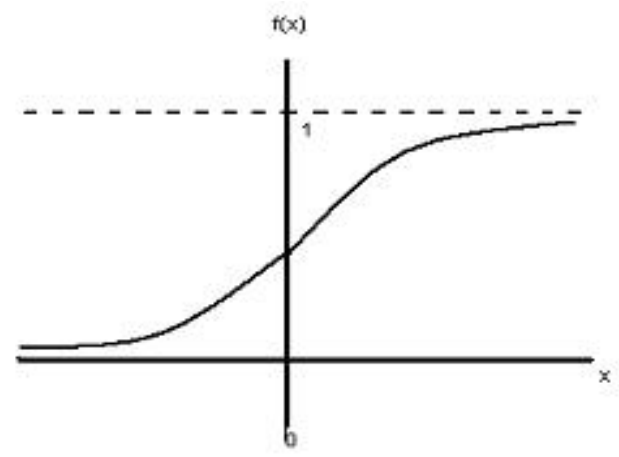

\section{Gambar Fungsi Sigmoid Biner}

Sedangkan fungsi sigmoid bipolarmemiliki range $(-1,1)$ didefinisikan dengan rumus sebagai berikut.

$$
f(x)=\frac{2}{1+e^{-x}}-1
$$

Apabila persamaan tersebut diturunkan maka persemaan tersebut menjadi.

$$
f^{\prime}(x)=\frac{(1+f(x))(1-f(x))}{2}
$$

Terkadang dalam jaringan saraf tiruan ditambahkan sebuah unit masukan yang nilainya selalu $=1$. Unit yang mempunyai sifat demikian itu disebut bias, bias dapat diartikan sebagai sebuah inputan yang nilainya $=1$. Bias berfungsi untuk mengubah nilai threshold menjadi $=0$. Jaringan saraf tiruan backpropagation menggunakan bias dalam arsitektur jaringannya baik dalam input layer maupun dalam hidden layer. Jika menggunakan bias maka perhitungan di unit output adalah sebagai berikut:

$$
Y k=b+\sum x_{i} w_{i}
$$

\section{F. Algoritma Backpropagation}

Untuk lebih memperjelas mengenai algoritma Propagasi Balik. Demikian akan dijelaskan mengenai langkah-langkah algoritma dari awal sampai akhir beserta dengan perhitungan matematis setiap langkahnya.

\section{Algoritma Propagasi Balik}

1. Inisialisasi semua nilai bobot.

2. Selama belum tercapai kondisi berhenti, lakukan.

3. Untuk setiap input attribut lakukan.

4. Setiap Input Unit $\left(X_{i}, i=1,2, \ldots, n\right) \leftarrow$ Nilai Input

5. Setiap Hidden Unit $\left(Z_{j}, j=1,2, \ldots, p\right) \leftarrow \operatorname{Nilai} X_{i}(i=1,2, \ldots, n)$

6. Untuk Setiap Hidden Unit

7. Hitung $z_{i n}=v_{0 j}+\sum_{i=1}^{n} x_{i} v_{i j}$ 


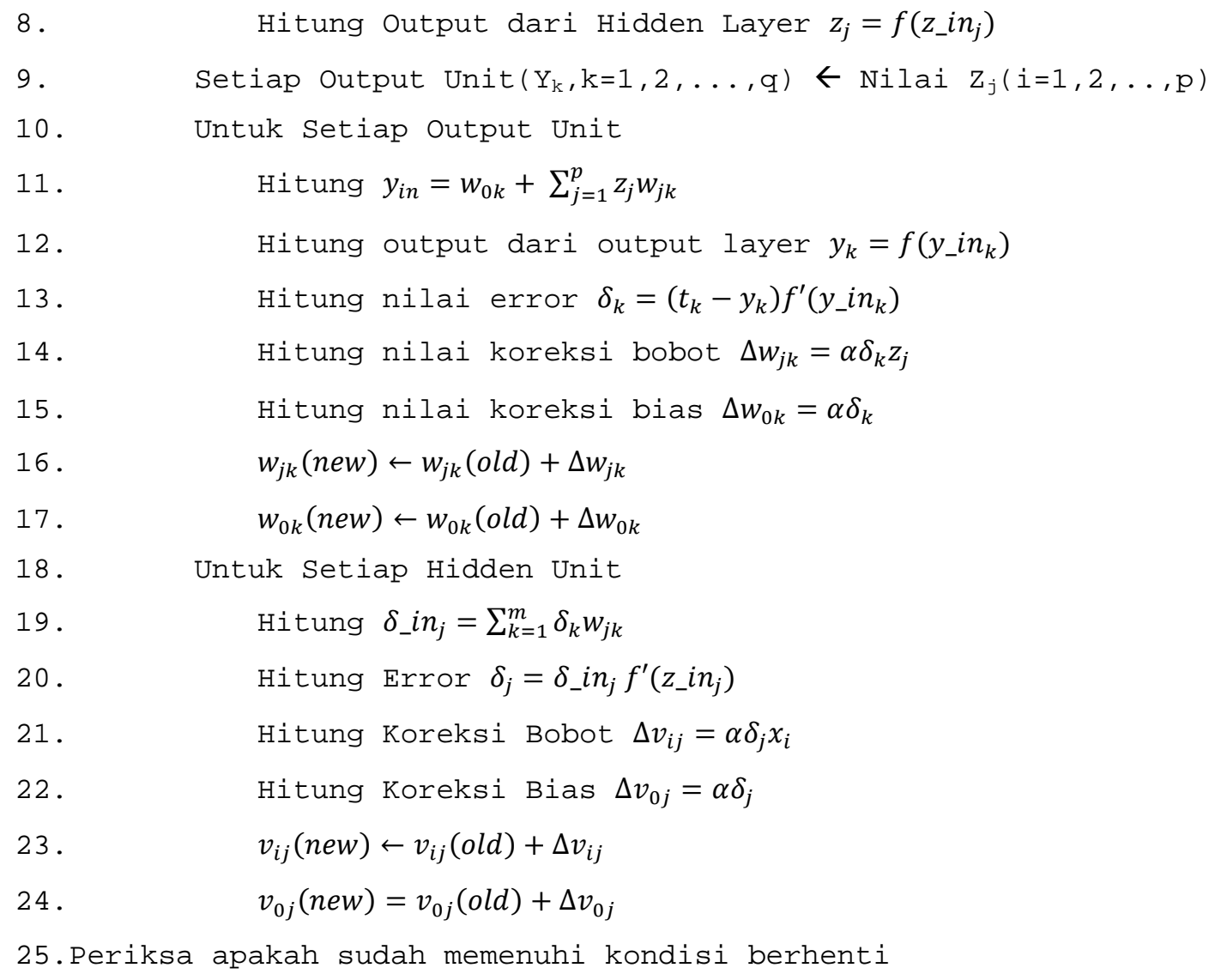

\section{HASIL PEMBAHASAN}

\section{A. Analisis Model Kebutuhan JST}

Dengan algoritma backpropagation, record data penjualan selama beberapa bulan atau tahun terakhir akan dipakai sebagai data pelatihan atau training, yang mana pada proses training ini bobot-bobot pada jaringan backpropagation akan melakukan perbaikan untuk mencari nilai yang optimal. Oleh karena itu, sebelumnya perlu ditentukan dulu besarnya periode dimana terdapat data yang fluktuatif. Dalam studi kasus untuk prediksi jumlah penjualan air mineral pada perusahaan "xyz” yang mana penjualan dapat terjadi tiap hari. Periode data dapat diambil selama satu bulan atau satu tahun. Namun, dalam hal ini dipilih data dalam periode satu tahun saja karena penjualan yang akan diperkirakan adalah penjualan pada bulan berikutnya.

Jumlah data dalam satu periode akan digunakan sebagai jumlah unit masukan dalam JST. Sedangkan sebagai target akan diambil data bulan pertama setelah periode berakhir. Pada data penjualan bulanan dengan periode dalam waktu satu tahun, maka masukan backpropagation yang akan dipakai terdiri dari 12 unit input dan 1 unit output. 
Hidden layer yang dipakai pada JST ini adalah 5 unit. Unit sebagai input yang dipakai adalah 12 mewakili data penjualan untuk setiap bulannya.

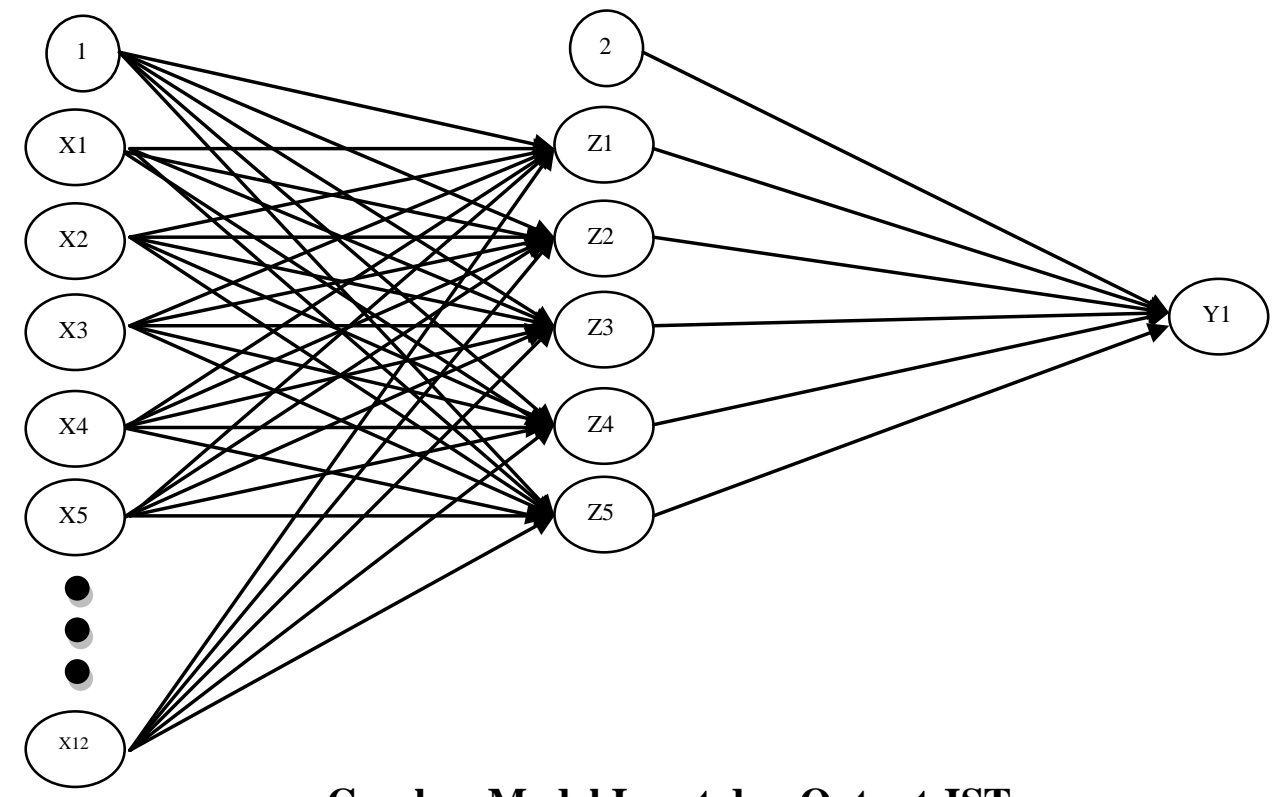

Gambar Model Input dan Output JST

\section{B. Prosedur Pengumpulan Data}

Dalam data preparation, data penjualan air mineral harus ditrasformasikan terlebih dahulu sebelum digunakan pada saat pelatihan atau training. Untuk melakukan transformasi data penjualan air mineral tersebut digunakan fungsi aktivasi sigmoid. Oleh karena dalam hal ini fungsi aktivasi sigmoid yang digunakan adalah fungsi aktivasi sigmoid(biner). Maka data harus ditransformasikan ke interval antara $[0,1]$, proses ini sering disebut sebagai normalisasi. Untuk mentransformasikan data ke interval $[0,1]$ digunakan transformasi linier.

$$
\begin{gathered}
x^{\prime}=\frac{0,9(x-a)}{b-a}+0.1 \\
\mathrm{a}=\text { Nilai minimum penjualan } \\
\mathrm{b}=\text { Nilai maksimum penjualan }
\end{gathered}
$$

Untuk lebih mengerti tentang penggunaan rumus diatas dibawah ini akan dijelaskan tabel penjualan air minum dari tahun 2004-2005.

Tabel Penjualan Air Minum

\begin{tabular}{|c|c|c|c|c|c|c|c|c|c|c|c|c|}
\hline \multicolumn{10}{|c|}{ Penjualan Air Mineral Per Bulan } \\
\hline Thn & Jan & Feb & Mar & Apr & Mei & Jun & Jul & Agu & Sep & Okt & Nop & Des \\
\hline 2004 & 10.620 & 7.725 & 3.284 & 2.400 & 1.767 & 1.463 & 1.090 & 1.070 & 1.355 & 5.324 & 7.167 & 13.780 \\
\hline 2005 & 9.590 & 5.291 & 3.081 & 2.147 & 2.045 & 1.696 & 1.341 & 1.181 & 1.613 & 2.242 & 6.161 & 10.430 \\
\hline
\end{tabular}


Data diatas adalah data penjualan air minum untuk setiap bulan pada tahun 2004-2005. Berikut ini adalah data penjualan air minum yang sudah dinormalisasikan menggunakan rumus normalisasi. Untuk lebih jelas mengenai proses perhitungan pada penjualan air minum pada tahun 2004 adalah sebagai berikut.

1. Dibentuk persamaan sebagai berikut

$$
x^{\prime}=\frac{0,9(x-1070)}{13780-1070}+0,1
$$

2. Contoh untuk bulan Januari pada tahun 2004 lakukan perhitungan sebagai berikut.

$$
\begin{gathered}
x^{\prime}=\frac{0,9(10620-1070)}{13780-1070}+0,1 \\
x^{\prime}=\frac{0,9.9550}{12710}+0,1 \\
x^{\prime}=0,776
\end{gathered}
$$

Tabel Hasil Proses Transformasi

\begin{tabular}{|c|c|c|c|c|c|c|c|c|c|c|c|c|}
\hline \multicolumn{10}{|c|}{ Penjualan Air Mineral Per Bulan } \\
\hline Thn & Jan & Feb & Mar & Apr & Mei & Jun & Jul & Agu & Sep & Okt & Nop & Des \\
\hline 2004 & 0.777 & 0.571 & 0.257 & 0.194 & 0.149 & 0.128 & 0.101 & 0.1 & 0.12 & 0.401 & 0.532 & 1 \\
\hline 2005 & 0.703 & 0.399 & 0.242 & 0.176 & 0.169 & 0.144 & 0.119 & 0.108 & 0.138 & 0.183 & 0.461 & 0.763 \\
\hline
\end{tabular}

Tabel diatas adalah data penjualan pada bulan ke-1 sampai dengan bulan ke-12. Data tersebut akan digunakan untuk memprediksi penjualan pada bulan ke-13 yaitu Januari 2005. Apabila diinginkan untuk melakukan prediski pada bulan ke-14 maka data yang dipakai sebagai training adalah data pada bulan-2 sampai dengan bulan ke-13. Nantinya akan terdapat 12 pola mewakili setiap bulan data yang akan diprediksi. Berikut ini adalah tabel contoh hasil penggunaan pola untuk melakukan prediksi pada tahun 2004-2005.

Tabel Pola untuk Prediksi (2004-2005)

\begin{tabular}{|r|rrrrrr|c|}
\hline \multicolumn{7}{|c|}{ Pola } & \multicolumn{7}{|c|}{ Data Masukan(x1,x2,...,x12) } & Target \\
\hline 1 & 0,77688 & 0,57124 & 0,25677 & 0,19418 & 0,14935 & 0,12804 & 0,7033 \\
& 0,10142 & 0,1 & 0,12018 & 0,40123 & 0,53173 & 1 & \\
\hline 2 & 0,57154 & 0,25677 & 0,19418 & 0,14935 & 0,12804 & 0,10142 & 0,39889 \\
& 0,1 & 0,12018 & 0,40123 & 0,53173 & 1 & 0,7033 & \\
\hline 3 & 0,25677 & 0,19418 & 0,14935 & 0,12804 & 0,10142 & 0,1 & 0,2424 \\
& 0,12018 & 0,40123 & 0,53173 & 1 & 0,7033 & 0,39889 & \\
\hline 4 & 0,19418 & 0,14935 & 0,12804 & 0,10142 & 0,1 & 0,12018 & 0,17626 \\
& 0,40123 & 0,53173 & 1 & 0,7033 & 0,39889 & 0,2424 & \\
\hline
\end{tabular}




\begin{tabular}{|r|rrrrrr|l|}
5 & 0,14935 & 0,12804 & 0,10142 & 0,1 & 0,12018 & 0,40123 & 0,16904 \\
& 0,53173 & 1 & 0,7033 & 0,39889 & 0,2424 & 0,17626 & \\
\hline 6 & 0,12804 & 0,10142 & 0,1 & 0,12018 & 0,40123 & 0,53173 & 0,14433 \\
& 1 & 0,7033 & 0,39889 & 0,2424 & 0,17626 & 0,16904 & \\
\hline 7 & 0,10142 & 0,1 & 0,12018 & 0,40123 & 0,53173 & 1 & 0,11919 \\
& 0,7033 & 0,2424 & 0,2424 & 0,17626 & 0,16904 & 0,14433 & \\
\hline 8 & 0,1 & 0,39889 & 0,40123 & 0,53173 & 1 & 0,7033 & 0,10786 \\
& 0,39889 & 0,17626 & 0,17626 & 0,16904 & 0,14433 & 0,11919 & \\
\hline 9 & 0,12018 & 0,40123 & 0,53173 & 1 & 0,7033 & 0,39889 & 0,13845 \\
& 0,2424 & 0,17626 & 0,16904 & 0,14433 & 0,11919 & 0,10786 & \\
\hline 10 & 0,40123 & 0,53173 & 1 & 0,7033 & 0,39889 & 0,2424 & 0,18299 \\
& 0,17626 & 0,16904 & 0,14433 & 0,11919 & 0,10786 & 0,13845 & \\
\hline 11 & 0,53173 & 1 & 0,7033 & 0,39889 & 0,2424 & 0,17626 & 0,4605 \\
& 0,16904 & 0,14433 & 0,11919 & 0,10786 & 0,13845 & 0,18299 & \\
\hline 12 & 1 & 0,7033 & 0,39889 & 0,2424 & 0,17626 & 0,16904 & 0,76328 \\
& 0,14433 & 0,11919 & 0,10786 & 0,13845 & 0,18299 & 0,4605 & \\
\hline
\end{tabular}

\section{Implementasi Algoritma Propagasi Balik}

Pada bagian ini akan dijelaskan mengenai implementasi dari algoritma propagasi balik yang digunakan untuk melakukan prediksi. Penjelasan dari implementasi ini akan dijelaskan dalam flowchart yang mewakili implementasi dari algoritma tersebut.

Flowchart ini mewakili gambar dari bagan propagasi balik pada Gambar input dan output dari JST. Dimana pada bagan tersebut terdapat beberapa attribut yang cukup penting diantaranya adalah 12 node pada lapisan input, 5 node pada lapisan tersembunyi, dan 1 node pada lapisan output. Notasi node untuk masing-masing lapisan ini dinotasikan menjadi:

1. Input Node adalah (x1, x2, x3, x4, x5, x6, x7, x8, x9, x10, x11, dan x12)

2. Node Tersembunyi adalah (z1,z2,z3,z4,dan z5)

3. Output Node adalah Yk

Dari masing-masing node pada input yang menghubungkan kedalam 5 node pada layer tersembunyi. Begitu juga dengan masing-masing node dari 5 node pada layer tersembunyi yang masuk kedalam output node. Garis yang menghubungkan dari input ke hidden layer dikodekan dengan $\mathrm{V}_{\mathrm{ij}}$. Sedangkan, garis yang menghubungkan antara layer tersembunyi dengan output node dikodekan dengan $\mathrm{W}_{\mathrm{kl}}$. 


\section{Proses Pelatihan}

Pada proses pelatihan ini akan digunakan inisialisasi epoch dan max alpha. Epoch yang digunakan pada saat pelatihan adalah 5000 dan max alpha yang digunakan adalah 0,001. Apabila epoch yang digunakan kurang dari nilai tersebut, maka akan terjadi error rate dari tebakan lebih tinggi.

Setelah itu program akan melakukan algoritma propagasi balik untuk tiap epochnya. Nantinya, proses pelatihan ini akan berhenti apabila epoch mencapai nilai 5000 atau max alpha sudah mencapai angka 0,01. Pada proses pelatihan untuk data ini epoch akan berhenti pada nilai 4108 dengan nilai 0,0009995666502555893 dengan nilai alpha adalah 0,001 .

\section{E. Proses Testing}

Setelah dilakukan proses pelatihan perangkat lunak akan memberikan notifikasi selesainya proses pelatihan dan menampilkan tampilan untuk proses testing. Nantinya pengguna harus memasukan nilai input mulai dari x1 hingga x12 untuk input data yang digunakan sebagai prediksi. Berikut ini adalah contoh input data yang digunakan untuk testing.

\section{Tabel Input untuk Prediksi Tes Pertama}

\begin{tabular}{|c|c|c|c|c|c|c|c|c|c|c|c|}
\hline X1 & X2 & X3 & X4 & X5 & X6 & X7 & X8 & X9 & X10 & X11 & X12 \\
\hline 0,12804 & 0,10142 & 0,1 & 0,12018 & 0,40123 & 0,53173 & 1 & 0,7033 & 0,39889 & 0,2424 & 0,17626 & 0,16904 \\
\hline
\end{tabular}

Setelah proses input data mesin prediksi akan melakukan perhitungan matematis untuk melakukan prediksi. Prediksi ini akan menghasilkan nilai yang dihasilkan dari tabel pola pada bagian 3. Dari input tersebut dihasilkan nilai 0,14045058069725105, dimana nilai ini mendekati nilai dari pola ke-6. Pola ke-6 bernilai 0,14433 hasil ini cukup mendekati. Perbedaan nilai ini dikarenakan oleh nilai input yang dimasukan tidak sama persis dengan pola yang terdapat pada baris ke-6. Akan tetapi, nilai ini masih bisa diterima.

Proses uji coba kedua akan dicoba menggunakan data input $\mathrm{x} 1$ sampai dengan x12 yang lain. Berikut ini adalah tabel input yang digunakan untuk prediksi pada uji coba kedua.

\section{Tabel Input untuk Prediksi Tes Kedua}

\begin{tabular}{|c|c|c|c|c|c|c|c|c|c|c|c|}
\hline X1 & X2 & X3 & X4 & X5 & X6 & X7 & X8 & X9 & X10 & X11 & X12 \\
\hline 0,12804 & 0,10142 & 0,1 & 0,12018 & 0,40123 & 0,53173 & 1 & 0,7033 & 0,39889 & 0,2424 & 0,17626 & 0,16904 \\
\hline
\end{tabular}


Dari perhitungan dari uji coba yang kedua didapatkan hasil dengan nilai 0,13647602156323518. Nilai ini mendekati nilai pada pola ke-6 dengan nilai error yang jauh lebih besar dari uji coba yang pertama. Akan tetapi hasil ini masih bisa ditoleransi mengingat range dari pola yang digunakan sudah memenuhi pola ke-6. Apabila digunakan input lain yang sama sekali tidak mirip dengan data pada pola, maka output dari tes ini menghasilkan nilai yang sangat jauh dari nilai pada tabel pola.

\section{KESIMPULAN DAN SARAN}

\section{A. Kesimpulan}

Dari pembahasan pada bagian-bagian sebelumnya, maka dapat ditarik beberapa kesimpulan sebagai berikut:

1. Kecepatan Jaringan Saraf Tiruan dalam melakukan prediksi suatu input data dipengaruhi oleh beberapa hal yaitu model input yang digunakan sebagai pelatihan dan pemilihan bobot.

2. Pemilihan bobot sangat mempengaruhi nilai dari fungsi aktivasi. Apabila fungsi aktivasi memiliki nilai yang rendah, maka proses perubahan bobot pada setiap iterasi menjadi sangat kecil dan proses iterasi menjadi lebih panjang untuk melakukan adaptasi terhadap proses pelatihan.

3. Input data pada saat proses testing apabila ditemukan persamaan dengan pola, maka prediksi yang dilakukan akan semakin akurat.

4. Apabila input data pada saat proses testing diinputkan dengan data yang tidak mempunyai kemiripan dengan tabel pola, maka data tersebut tidak akan dikenali oleh JST ini.

5. Penambahan pola dalam JST perlu ditambahkan untuk meningkatkan akurasi dari prediksi yang dihasilkan.

\section{B. Saran}

Dari pembahasan pada bagian-bagian sebelumnya, penulis menyarankan perbaikan-perbaikan yang harus dilakukan untuk penelitian lebih lanjut adalah sebagai berikut.

1. Penambahan jumlah hidden unit akan sangat mempengaruhi kinerja JST dalam melakukan prediksi suatu input pada saat testing. 
2. Penggunaan Jaringan Saraf Tiruan untuk melakukan prediksi kurang efektif. Hal ini disebabkan oleh variansi pola yang sangat beragam dan tidak mungkin untuk mengenali data penjualan secara akurat.

3. Kecepatan pelatihan dari tiap epoch perlu ditingkatkan apabila pada lapisan input ditambahkan beberapa input node yang baru.

\section{REFERENSI}

[1] Anderson, Dave dan Mcneill. Artificial Neural Networks Technology. Kaman Sciences Corp 1992

[2] Gunawan, 2007. Handout Mata Kuliah ANN Semester Genap 2006-2007. IKADO.

[3] Kusuma, Sri. Membangun Jaringan Saraf Tiruan Menggunakan MATLAB dan Excel Link,. Graha Ilmu Jakarta, 2004.

[4] Rao, Valluru. C++ Neural Networks and Fuzzy Logic. IDG Books Worldwide, Inc.

[5] Smith, Kate dan Jatinder Gupta, 2002. Neural Networks in Bussiness: Technique and Application, Idea Group Publishing . 